\title{
Presentation of the Howland Award to Dr. Saul Krugman
}

\author{
JOSEPH DANCIS \\ New York University-Bellevue Medical Center, New York, New York, USA
}

This is the second time in 2 years that I am standing before you in this most delightful role, that of presenting a very good friend for the honor of the Howland Award. Last year, it was Henry Kempe, and I spoke for Henry Silver. This year, it is Saul Krugman, and I speak for myself.

There is no need for me to introduce Saul to you. I daresay that very few of you have not already encountered him in the course of his perennial travels, have not heard him lecture, have not studied his text, or have not read about him in the science section of the Times. What I plan to do is to describe briefly the road traveled by Dr. Krugman culminating in this coveted award given "For Distinguished Service in Pediatrics."

Let us start at the beginning. Saul was born in New York City on April 7, 1911. For those of you without pocket calculators, he is now 70 years old. When he was still a youngster, the family moved to Paterson, New Jersey, where Saul was enrolled in the public school system, duly graduating from high school at the age of 18. A review of the high school yearbook in search of significant biographical notes elicits a description of a serious student already developing the skills and experiences necessary for survival in modern-day academia. He was on the student council, a debator, a member of the dramatic society, and he possessed a "good business head." These skills have served him well. Even his love of dancing, much admired in high school, has been exhibited in later years as a vitruoso performance of the Charleston at the annual graduation dance at NYU.

In 1929, Saul matriculated at Ohio State University but was forced to drop out after his third year. These were those severely troubled years in the United States, the critical period known as the great depression, a time of uncertainty, confusion, and hardship difficult to comprehend for those of you who had not yet been born. Saul's response was to use the next 2 years to improve his technical skills in waiting on tables, selling shoes, and whatever else, while burrowing away the funds that permitted him to complete his premedical requirements and obtain an M.D. degree from the Medical College of Virginia.

The customary 2-year rotating internship was undertaken at little-known Cumberland Hospital in Brooklyn in 1941. At the end of his training, Saul joined the Army, presumably for 2 years of service. It proved to be a 5-year term covering World Wall II. Much of the time he spent as Flight Surgeon, island hopping around the Pacific. It may have been then that he developed his delight in challenging the clock during his later travels - a morning in Bethesda, a day in Paris with a stopover in Athens, and back to Bellevue by 1 PM in time for the Infectious Disease Conference. While most of us bumble around airports looking for lost luggage Saul gets there in time.

It was in 1946 that Dr. Krugman arrived at Bellevue as an externe in Pediatrics. (For the uninitiated, an externe was a euphemism for an interne who did not qualify for even the meager support offered at the time). At 35 years of age, he was viewed as an anomalous addition by the young, bright house staff who had been accelerated through school to provide medical care for the home front. His only visible assets were his wife, Sylvia, and young son, Dick, soon to be joined by Carol-all of whom are still visible and still assets-a quiet, conscientious demeanor, and an interest and skill in what was then called "contagion." An interview by an Interne Selection Committee of today would surely rate him as average and suggest that he had already made

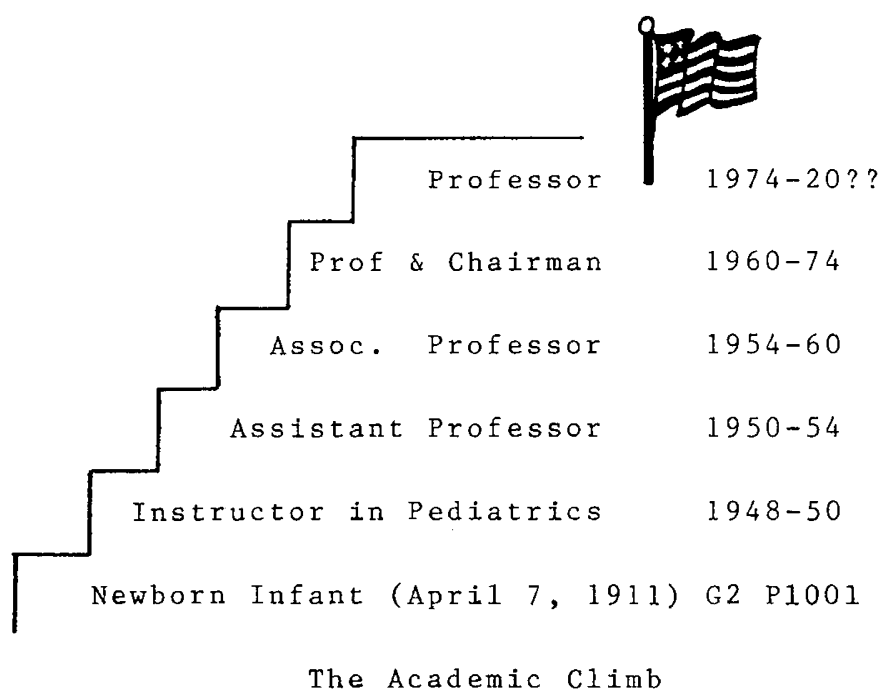

Table 1. Professional appointments

Member, Committee on Plasma and Plasma Substitutes National Research Council, 1963-69.

Member, National Advisory Council, National Institute of Allergy and Infectious Diseases, 1965-69.

Member WHO Expert Advisory Panel on Virus Diseases, 1968-

Member and Deputy Director, Commission on Viral Infections, Armed Forces Epidemiological Board, 1968-73.

Member, Scientific Program Committee, American Academy of Pediatrics, 1969-73.

Member, Editorial Board The Journal of Infectious Diseases, 1969-74.

Chairman, Task Force on Rubella, National Center for Voluntary Action, 1970-73.

President, Pediatric Section, Pan American Medical Association 1970-73.

Member, Committee on Infectious Diseases, American Academy of Pediatrics, 1970-74.

Chairman, Infectious Disease Advisory Committee National Institute of Allergy and Infectious Diseases, 1971-73.

Chairman, Committee on Viral Hepatitis National Research Council, 1973-76.

Chairman, Food and Drug Administration Panel on Review of Viral and Rickettsial Vaccines, 1973-79.

Member of the Advisory Board, The Journal of Pediatrics, 1974.

Consultant, Bureau of Biologics, Food and Drug Administration, 1979-

Chairman, Hepatitis Panel, U.S.-Japan Cooperative Medical Science Program, October 1, 1979-

Consultant, National Institutes of Health, NIAID, 1979-

Member, Scientific Committee, The New York Blood Center, June, 1980Associate Editor, Hepatology 1980- 
several giant steps towards the anonymity reserved for the good but undistinguished pediatrician.

Nothing would have changed that judgment during the first several years at Bellevue. During these years, stars were rapidly being born under the careful, subtle cultivation of Emmett Holt and Bob Ward, soon to leave NYU to chair departments across the country and to earn reputations as investigators. Saul, drinking fully at the same well, was undergoing a slow incubation. To mix metaphors completely, this late bloomer was sinking a rich root system and developing the first green shoots, but the blossoms were to come much later.

It is not possible to talk of Saul's professional accomplishments without dwelling on the Willowbrook State School. The story is one of a felicitious union of skills as yet untapped and opportunities waiting to be grasped. Willowbrook State School at that time housed hundreds of retarded children and was soon to

Table 2. Awards and honors

Alpha Omega Alpha Honorary Society

Haven Emerson Award, 1967

American College of Physicians - James D. Bruce Memorial Award, 1972.

The John M. Russell Award (Markle Foundation), 1972.

Charles H. Hood Foundation's Child Health Award, 1972.

The Grulee Award, American Academy of Pediatrics, 1975.

President, American Pediatric Society, 1972-73.

Vice-President, American Epidemiological Society, 1974-75.

Infectious Diseases Society of America Bristol Award, 1976.

The Gold Medal Award, Phi Lambda Kappa Fraternity, 1976.

Elected to National Academy of Sciences, 1976.

Elected Fellow, American Academy of Arts and Sciences, 1977.

New York Academy of Medicine Medal, 1978.

Robert Koch Gold Medal Award, 1978.

Honorary Doctor Science, Ohio State University, 1979

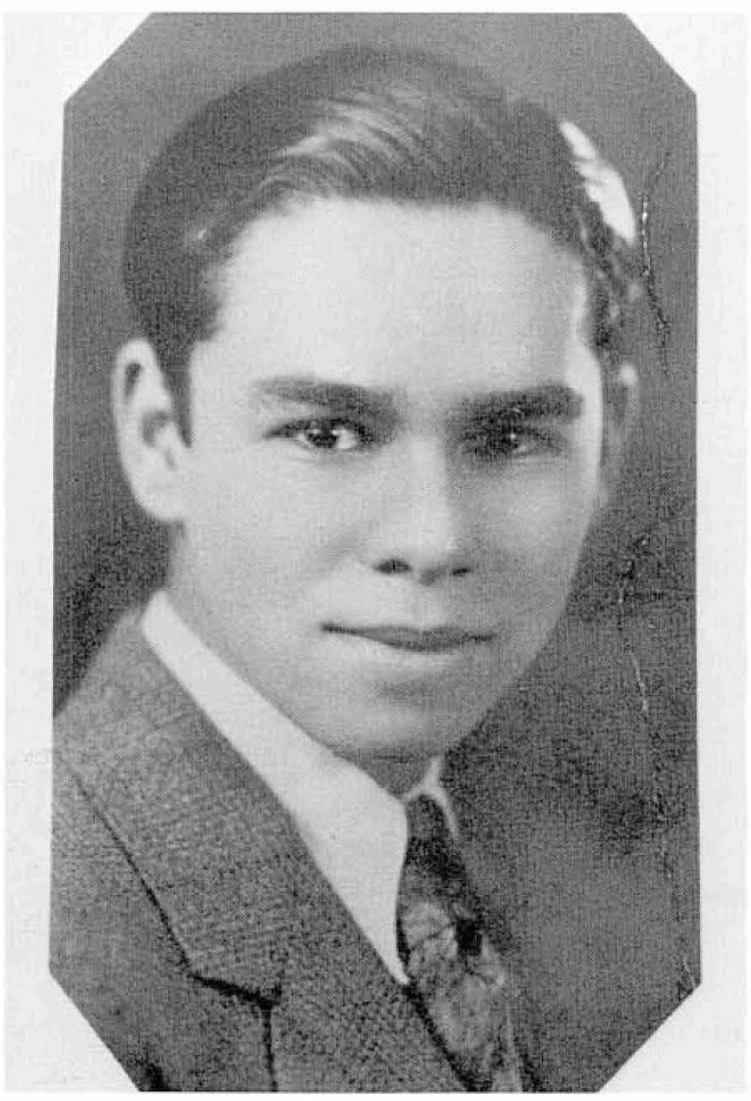

Fig. 2. Saul Krugman in high School. increase its population to thousands. Neglected by society and served by an inadequate staff, the patients, or "clients" as they are now called, were plagued by simmering endemics, punctuated by explosive outbreaks of disease. The administration turned to the experts at NYU, Bob Ward and Saul Krugman, for advice and help, and they responded.

The appearance on the scene of capable physicians, interested in their problems, bringing hitherto unavailable resources with them was greeted eagerly by the overwhelmed staff, the harrassed administration, and the guilt-ridden parents. The fruits of their efforts were soon to be seen. Measles, a far more serious disease among these institutional children than in the normal subject, had been a scourge, visiting in epidemics each time a group of newly admitted susceptible children had accumulated. Measles vaccine, just approved for clinical testing, received its first extensive field trial at Willowbrook in 1961, and there has not been a single case of measles at the institution ever since. Rubella was soon to follow the same path of extinction.

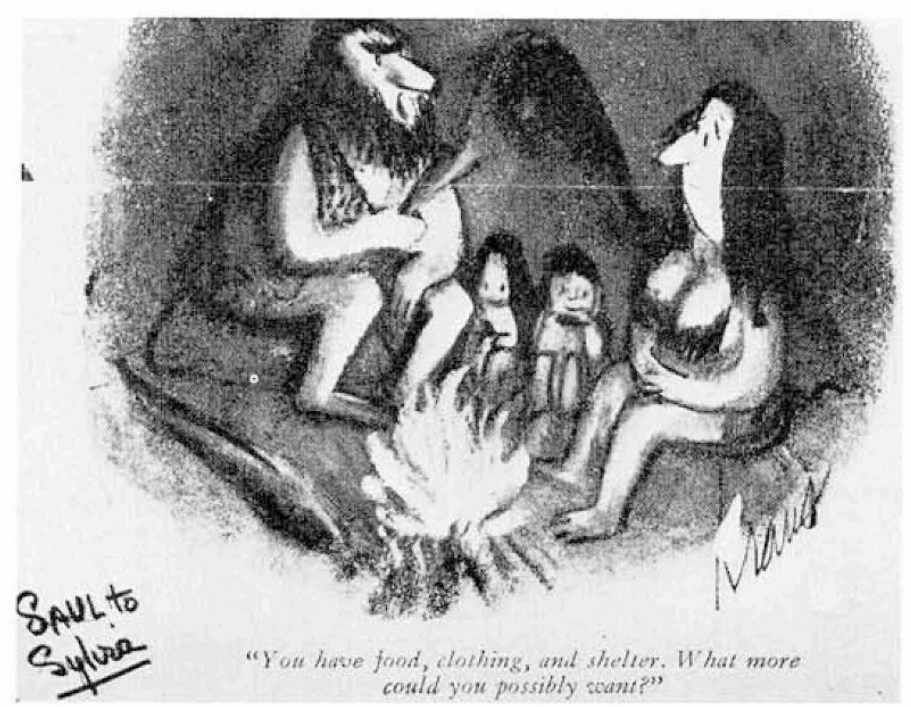

MEW YORK UMIVERSITY MEDICAL CENTER

TRANSMITTAL SLIP

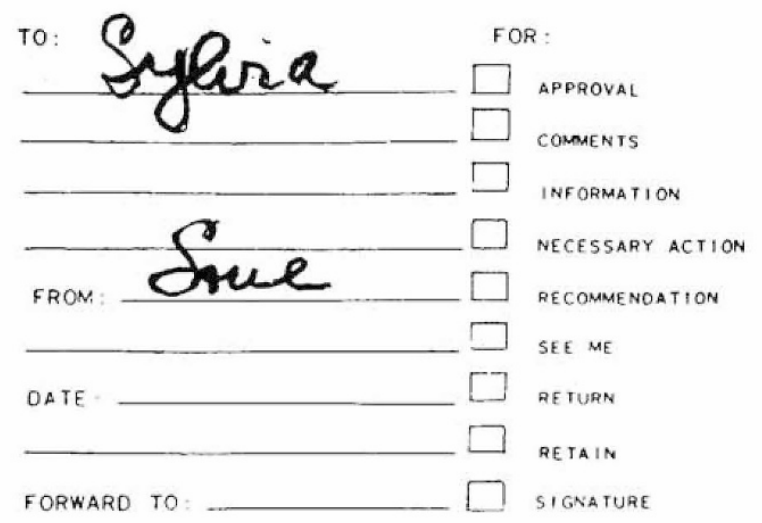

REMARKS

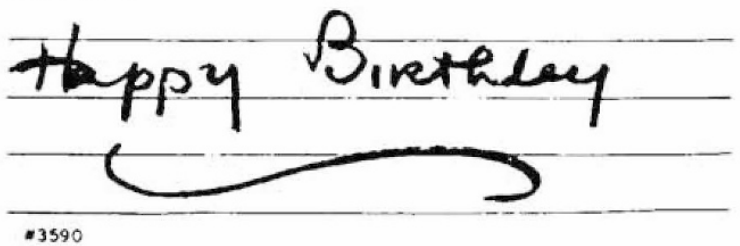


However, it is the unfolding of the saga of hepatitis that I have enjoyed most from my front row seat in the mezzanine. It is a rare example of the accomplishments of expert clinical skills supported by simple laboratory tests. It is a triumph of careful observation and meticulous records, of accumulated precious samples collected from patients and hoarded for years, all interlaced with imaginative leaps in interpretation.

Hepatitis was endemic at Willowbrook, affecting patients and caretakers alike. Nobody realized the extent of the involvement until the team from New York University presented evidence that virtually all patients and their attendants were infected sooner or later after admission. Further careful observation defined the natural history of the disease, exposing in the process the unexpected existence of two types of hepatitis rampant in Willowbrook. Pursuit of this clue led to the even more startling realization that "serum hepatitis," now known as Hepatitis B, did not require the intervention of a malevolent needle for dissemination, relying instead on the direct route of contact with infected secretions. This segment of the history reached its apogee with that simple but brilliant experiment. Serum from infected patients which was exposed to the temperature of boiling water for $1 \mathrm{~min}$ protected susceptibles against disease. I remember the excitement when Saul first showed me the data in his office in old Bellevue Hospital. The key to the control of Hepatitis B, the development of a vaccine, was now available without waiting for the bench scientist to tame the recalcitrant virus. A decade later, the prophesy is being fulfilled. Effective vaccines have been prepared from human donors using the astounding population of virus particles that circulate in their blood. The control of Hepatitis B is within our grasp.

The name, The Willowbrook State School, conjures up another image for some, one of unethical experiments conducted in secrecy on helpless inmates to satisfy a cold scientist's quest for knowledge and fame. This Frankensteinian picture which had no relation to
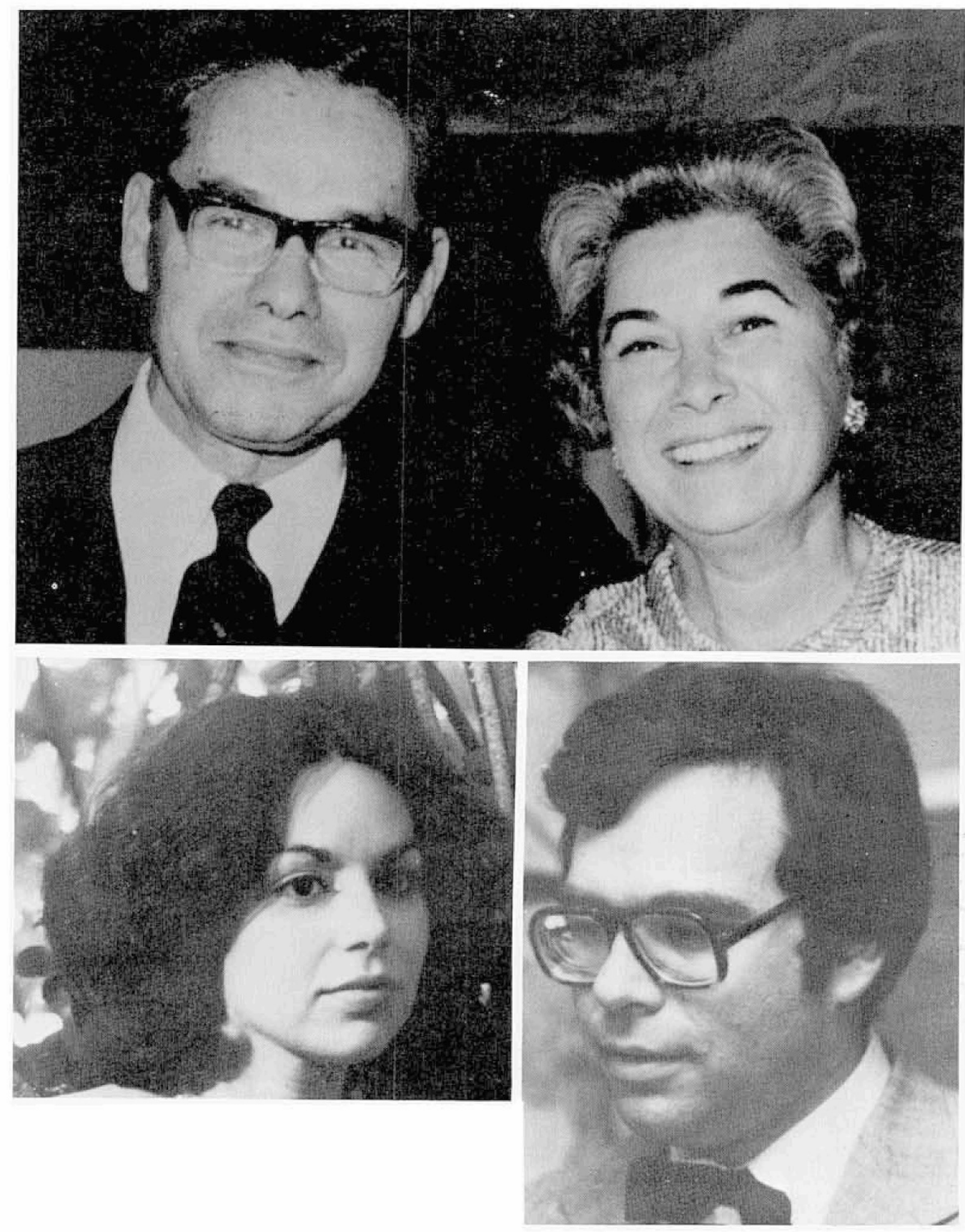

Fig. 5. Saul and Sylvia Krugman with Carol and Dick. 
the truth, served to inflame passions and excite ferocious attacks on Dr. Krugman's integrity.

During these troubled years, I became aware of another Saul Krugman which I did not know existed. Convinced of the propriety and the value of his work, he stood firm in the face of extreme pressure, refusing to respond in kind to invectives, trying vainly to meet passion with reason. The pain that he felt and demonstrated to few was intense, accustomed as he was to the approbation reserved for the kind and generous physician devoted to his patients and to his profession.

Much has been written and much has been said about the Willowbrook studies and differences of opinion still persist. What is clear is that highly motivated and principled people-and I include with Saul Krugman Bob Ward, Joan Giles, and the exceptional nursing and technical staff-applied themselves for years to the medical problems of an isolated and neglected group of children with great benefit to their subjects and to children everywhere. Their studies were done in the light of day with the eager acceptance of parents and with the approval of committees of experts established to judge and monitor their activities. What could be done to conform to existing standards was done, and more exacting standards were established in the process.

Dr. Krugman's renown does not rest solely on his accomplishments at Willowbrook. His studies have taken him far afield, to Israel, Africa, and Greece. Nor are his contributions limited to research. As Chairman of Pediatrics at New York University for 14 years, he guided and inspired a generation of medical students and hospital residents. As a popular lecturer and spirited panelist, he has extended his influence as an educator far beyond the University. Through his book, he has become the final authority on Infectious Diseases for pediatricians everywhere.
I have prepared a few tables to provide an indication of the scope of his activities. The first depicts his climb up the academic ladder to the ultimate, that of being Professor and no longer Chairman (Fig. 1). Then we have a list of some of his professional assignments (Table 1), and finally, some of the more prestigious awards that have been showered upon him (Table 2).

So far, I have described Saul from my vantage point, that of a colleague. I thought you might also like to know Saul as his family sees him. I asked Sylvia Krugman to help me with that message.

First, we see Saul as a high school student (Fig. 2). The cartoon (Fig. 3) depicts him as a Fellow or junior faculty member. The caption might have been "His first important lecture." I doubt that the incident ever took place, but it could have many times. Firm as Saul could be, there was always time for thoughtful tenderness (Fig. 4). And, finally, there is a picture of Saul as he is today, with his family (Fig. 5).

Now that I have told all, it is only reasonable to wonder as to the qualities of character that made them possible. An obvious feature is his persistent enthusiasm and optimism. As his contemporaries grow appropriately older, Saul resists time. His approach to life and his career stems from a previous generation. When it is assumed that good research requires elaborate equipment and sophisticated technology, Saul relies on the skilled eye of a clinician and a syringe and needle. When textbooks have become compendia for a group of experts, Saul's highly acclaimed book remains the result of a very personal effort in collaboration with one close friend and colleague, at first Bob Ward and now Sam Katz. At a time when the ideal is a well-balanced life of varied interests, Saul offers a life of total concentration and commitment. The prescription of another era is the key: "love and work": love of family, loyalty to friends, and devotion to work. 